\title{
Articles
}

\section{Overview of Research on Relics of Yu the Great}

\author{
ŌWAKI Yoshio*
}

Note: In this paper, the terms “Wenming” 文命(Jpn: Bunmei), “Yu” (禹), “Yuwang” (禹王), “Dayu” (大禹), “Xiayu” (夏禹), and “Shenyu” (神禹)are all used to refer to Yu the Great. [Translator's note: original Chinese pronunciations have been used in references to $\mathrm{Yu}$ the Great.]

\section{Yu and Wenming}

According to the ancient Chinese text, the Shiji 史記 (Records of the Grand Historian), completed by Sima Qian (司馬遷)around 91 BCE, Yu's surname was Si (姒) and his first name was Wenming (文命). His posthumous title was $\mathrm{Yu}$ (禹). Here I will introduce the most important texts related to this issue.

“Xia Yu ming yue Wenming, Yu zhi fu yue Gun” 夏禹名曰文命、禹之父 曰鯀 (Yu of the Xia dynasty was called Wenming. Yu's father was called Gun.") in "Annals of Xia, No.2," in Records of the Grand Historian.

“Taizi gong yue: Yu wei Si xing, qihou fenfeng...”太子公曰：禹為姒姓、 其後分封 (Taizi Gong says: Yu's family name was $\mathrm{Si}$; later, he was conferred a title to a feudal state...) Ibid.

Note: Taizi Gong refers to Sima Qian.

“Wenming shi wei Yu” 文命是為禹 (Wenming is Yu) in “Genealogical Table of the Three Ages" (三代世表), Vol.13, Records of the Grand Historian.

"Huangdi chan Changyi; Changyi chan Gaoyang, shiwei Di Zhuanxu; Zhuanxu chan Gun, Gun chan Wenming, shiwei Yu” 黄帝産昌意、昌意産高 陽、是為帝顓頊、顓頊産鯀、鯀産文命、是為禹（The Yellow Emperor begat Changyi; Changyi begat Gaoyang, who was the emperor, Zhuanxu; Zhuanxu begat Gun; Gun begat Wenming, who was Yu...) in Vol.6, Dadai Liji 大戴禮 (Book of Rites by Dai Senior).

“Kongzi yue: Gaoyang zhi sun, Gun zhi zi ye, yue Wenming...”孔子 曰高陽之孫、鯀之子也、曰文命 (Confucius said: Gaoyang’s grandson was Gun, who had a son called Wenming) in Vol.7, Dadai Liji.

Note: Daide (戴徳), the author of the Dadai Liji, lived in the Former Han

* Ōwaki Yoshio 大脇良夫 is Chairman of the Research Society on Chisuigami and Yu the Great. 
dynasty (birth and death dates unknown).

There are many such examples in Japan, too. For example, to use a famous person from my own area, Ninomiya Sontoku (二宮尊徳), we can say: “The surname is Ninomiya (二宮), and the given name is Kinjirō (金次郎). His posthumous name is Sontoku (尊徳).” Yu was the posthumous name for Wenming in the same way that Sontoku was the posthumous name for Kinjirō.

\section{Inception and Development of Research on Relics of Yu the Great (Wenming)}

January, 2006

Research began when the newly-established local private research group, Ashigara Historical Rediscovery Club足柄の歴史発見クラブ, (first president: this author), sponsored as one of the group's events, an outing in October for local elementary and junior high school students to enable them to become easily acquainted with local history by observing the words on the monument for Wenming that was built on the levee of the Sakawagawa River. The monument reads: "Wenming is $\mathrm{Yu}$ the Great, the flood control god who controlled the Yellow River and was the founder of the Xia dynasty" (中国の 夏王朝の祖であり黄河治水神の大禹であること).

We were astounded to learn from the inscription (found in its entirety on page 14) on the "Wenming east levee monument" that was built in 1726 on the local Sakawagawa River and Ōkuchi embankment that there was "also a temple for worshipping Yu the Great on the Kamogawa River in Kyoto."

November 2006

We visited the Kyoto Historical Museum and the Kyoto civil engineering office, and proved the existence of a monument to $\mathrm{Yu}$ the Great by doing joint research until March 2007. The following was discovered:

1) The monument to $\mathrm{Yu}$ the Great did indeed exist along the Kamogawa River between Shijō and Gojō (from about 1228 to the latter 1500s, just before the Edo period), but is no longer extant.

2) We were able to verify, however, the existence of relics of Yu the Great along the Yodogawa River (Shimamoto-chō, Osaka Prefecture); Tonegawa River (Katashinamura and Numata City, Gunma Prefecture); Usuki City, Ōita Prefecture; and Takamatsu City, Kagawa Prefecture.

If we had not done investigative work on number 2 above, there would have been no links for further inquiries into Yu the Great relics. Our joint research with the Kyoto civil engineering office was truly significant. 
2007-2009

While doing fieldwork on extant $\mathrm{Yu}$ the Great relics and the Yuwang Temple that previously existed along the Kamogawa River in Kyoto, we also held roundtable discussions with local researchers in locales where relics are located, thereby creating many opportunities for exchange. By the end of 2009 we were able to ascertain the existence of $\mathrm{Yu}$ the Great relics in a total of 18 places.

2010

On November 27 and 28 of 2010 we held the "First National Yu the Great (Wenming) Summit" in Kaiseimachi, Kanagawa Prefecture. It was such a big event locally and outside the area that NHK News broadcast information on it, thereby exciting some interest. Ever since we began holding the summit, interest in the relics of $\mathrm{Yu}$ the Great has increased. The number of relics discovered began increasing dramatically.

2012

The second summit was held in Katashinamura, Gunma Prefecture. The number of places with relics reached 50 .

2013

The third summit was held in Takamatsu City, Kagawa Prefecture. The number of places where relics were discovered reached 63 .

2014

The fourth summit was to be held in Hiroshima City, Hiroshima Prefecture. Large landslides that occurred shortly before the summit was to open, however, resulted in deaths in the area. The summit itself was cancelled, but it is still listed in the records of the journal as having taken place. The number of places with $\mathrm{Yu}$ the Great relics stood at 83 as of this point.

2015

The fifth summit was held in Usuki City, Ōita Prefecture. The number of places with relics reached 92 .

2017

The sixth summit is scheduled to be held at the Fuji River basin in Yamanashi Prefecture. 


\section{Summary and Characteristics of Japan's Yu the Great (Wenming) Relics}

\section{日本禹王遺跡の時代別・種別一覧}

2015年 4 月 1 日現在大脇 良夫

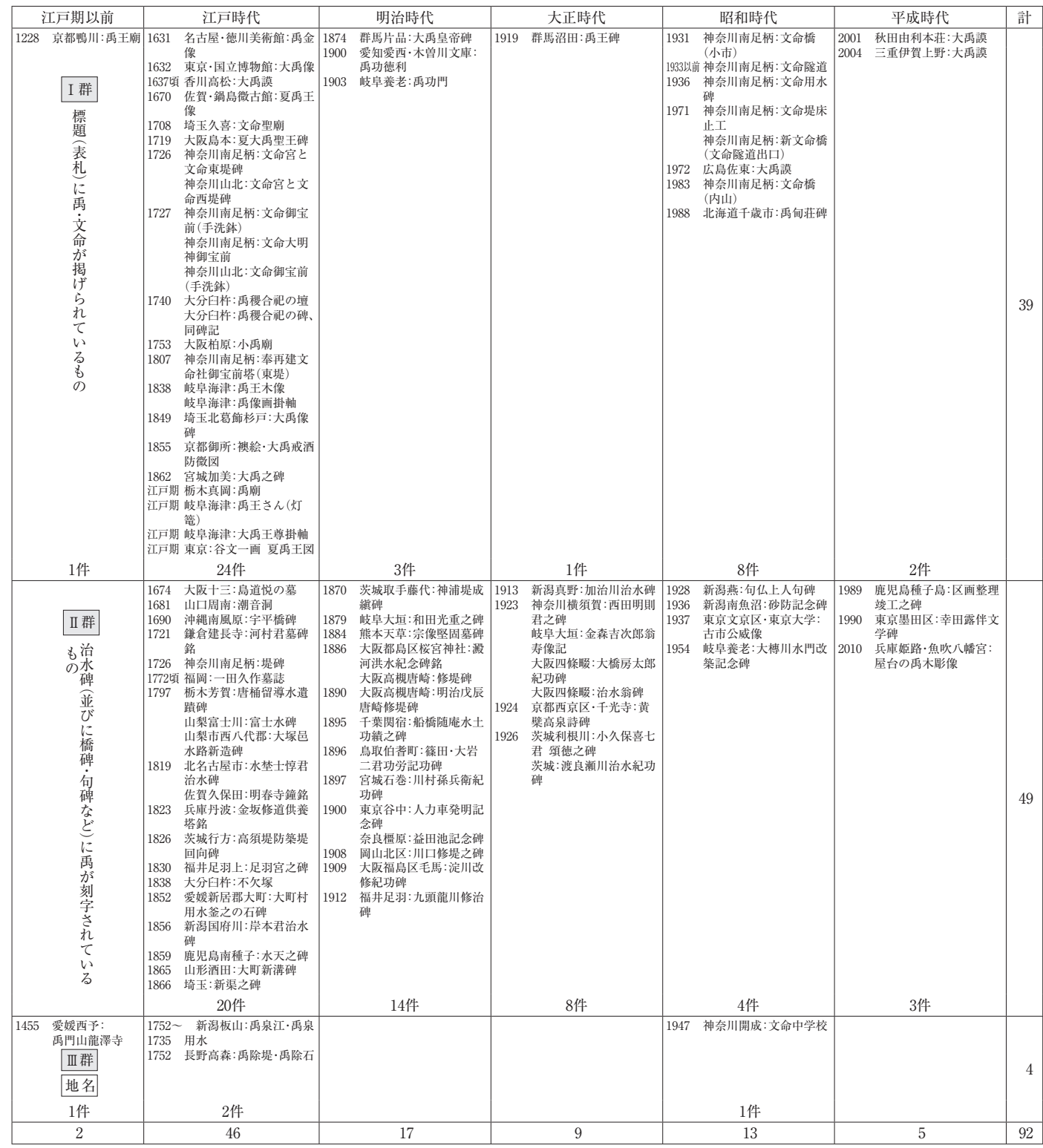

1) Characteristics by era: Before Edo period: 52\%; Meiji period: 18\%; Taishō period: 10\%; Shōwa and Heisei periods combined: $20 \%$.

Seventy percent (65 locales) were built by the Meiji era, but building continued in the Taishō (9 places), Shōwa (13 places), and Heisei (5 places) periods. 
Types of monuments:

Group I: In the titles on the monuments, $42 \%$ are inscribed with the words, "Yu," "Yu Wang," "Xia Yu," "Da Yu," or "Wenming" (39 places). Of these, 15\% are "Wenming" (14 places) and are concentrated in the Sakawagawa River basin.

Group II: Yu the Great is cited in 53\% of the monuments (49 places) for flood control, bridge monuments, haiku-inscribed stone tablets, and other monuments (Example: completion of grand levees and canals that are comparable to Yu the Great's prowess in controlling flooding. Many of the inscriptions are of Yu the God.)

Group III: The remaining 5\% (4 places) are examples that occur in regional, school, or temple names.

3. Characteristics by region: Most are in major river basins, such as the Tonegawa, Sakawagawa, the three rivers that comprise the Kisogawa and the Yodogawa. They are also distributed evenly along the archipelago from Hokkaido to Okinawa, and from the Pacific Ocean to the Japan Sea side.

4. Significance of the 30 monuments built during the period of Sino-Japanese disputes (78 years, from 1894 to 1972).

1) Of the 92 places, 30 were built after the First Sino-Japanese War (1894-1895) and before the time of normalization of relations with the People's Republic of China in 1972.

Even during tensions between the two countries, which had an adversarial relationship, monuments to Yu Wang (Wenming) continued to be built and the flood control god worshipped in various locations throughout the Japan. It is thought that China's god of flood control came to be accepted as Japan's god of flood control, and cherished as an entity that transcends nationality and ethnicity (as a god of flood control common throughout Asia or the world). Yu (Wenming) was seen as an idealist who works diligently and endures hardships, and was thus easy for Japanese to identify with. He is so described in particular in the Records of the Grand Historian (史記). He is also mentioned in Zhuangzi (莊子), and the Shanhai jing (山海經; Classic of Mountains and Seas), where it says, "Yu is crippled."

2) The twenty main sites of the thirty built during the 78 years between 1894 and 1972 are listed chronologically as follows:

\begin{tabular}{|l|l|l|l|}
\hline Year & $\begin{array}{l}\text { Relic Name and Name of } \\
\text { Yu Carved on Monument }\end{array}$ & $\begin{array}{l}\text { Location (Water System } \\
\text { and Prefecture) }\end{array}$ & $\begin{array}{l}\text { Main Events between } \\
\text { Japan and China }\end{array}$ \\
\hline 1895 & $\begin{array}{l}\text { 船橋隋庵水土功績之碑 } \\
\text { 「大禹聖人」 }\end{array}$ & $\begin{array}{l}\text { Tonegawa, Noda City, } \\
\text { Chiba Prefecture }\end{array}$ & $\begin{array}{l}\text { 1894-1895 } \\
\text { First Sino-Japanese War }\end{array}$ \\
\cline { 1 - 2 } 1896 & $\begin{array}{l}\text { 篠田・大岩二君功労記功碑 } \\
\text { 「神功禹蹟」 }\end{array}$ & $\begin{array}{l}\text { Hinogawa, Hōkichō, } \\
\text { Tottori Prefecture }\end{array}$ & \\
\cline { 1 - 3 } 1897 & $\begin{array}{l}\text { 川村孫兵衛紀功碑 } \\
\text { 「神禹以後唯有公」 }\end{array}$ & $\begin{array}{l}\text { Kitagamigawa, Ishinomaki } \\
\text { City, Miyagi Prefecture }\end{array}$ & \\
\hline
\end{tabular}




\begin{tabular}{|c|c|c|c|}
\hline 1900 & \begin{tabular}{|l} 
禹功徳利 \\
「其業何為袞禹功」
\end{tabular} & $\begin{array}{l}\text { Kisogawa, Aisai City, } \\
\text { Aichi Prefecture }\end{array}$ & \\
\hline 1900 & $\begin{array}{l}\text { 益田池記念碑 } \\
\text { 「前堯後禹」 }\end{array}$ & $\begin{array}{l}\text { Kashihara City, Nara } \\
\text { Prefecture }\end{array}$ & \\
\hline 1908 & 禹功門 & $\begin{array}{l}\text { Ibigawa, Yōrōgun, Gifu } \\
\text { Prefecture }\end{array}$ & \\
\hline 1908 & \begin{tabular}{|l|l|} 
川口修提之碑 \\
「鳴呼微禹吾其魚乎」
\end{tabular} & $\begin{array}{l}\text { Asahigawa, Okayama City, } \\
\text { Okayama Prefecture }\end{array}$ & \multirow{4}{*}{$\begin{array}{l}1911 \text { Xinhai Revolution } \\
1915 \text { Twenty-One } \\
\text { Demands by Japan on } \\
\text { China }\end{array}$} \\
\hline 1909 & $\begin{array}{l}\text { 淀川改修紀功碑 } \\
\text { 「以称神禹之功」 }\end{array}$ & $\begin{array}{l}\text { Yodogawa, } \\
\text { Miyakojima-ku, Osaka }\end{array}$ & \\
\hline 1912 & $\begin{array}{l}\text { 九頭龍川修治碑 } \\
\text { 「称功軼神禹矣」 }\end{array}$ & $\begin{array}{l}\text { Kuzuryūgawa, Fukui City, } \\
\text { Fukui Prefecture }\end{array}$ & \\
\hline 1919 & $\begin{array}{l}\text { 禹王之碑 } \\
\text { 「禹王之碑」 }\end{array}$ & $\begin{array}{l}\text { Tonegawa, Numata City, } \\
\text { Gunma Prefecture }\end{array}$ & \\
\hline 1923 & \begin{tabular}{|l} 
治水翁碑 \\
$\lceil$ 是頡頑神禹功」
\end{tabular} & $\begin{array}{l}\text { Yodogawa, Shijōnawate } \\
\text { City, Osaka }\end{array}$ & \\
\hline 1923 & $\begin{array}{l}\text { 大橋房太郎君紀功碑 } \\
\text { 「大禹ノ水 } 尹 \text { 治ムルヤ」 }\end{array}$ & $\begin{array}{l}\text { Yodogawa, Shijōnawate } \\
\text { City, Osaka }\end{array}$ & \\
\hline 1923 & $\begin{array}{l}\text { 西田明則君之碑 } \\
\text { 「大禹治水」 }\end{array}$ & $\begin{array}{l}\text { Tokyo Bay, Yokosuka City, } \\
\text { Kanagawa Prefecture }\end{array}$ & \\
\hline 1924 & $\begin{array}{l}\text { 黄檗高泉詩碑 } \\
\lceil\text { 何人治水功如禹」 }\end{array}$ & $\begin{array}{l}\text { Katsuragawa, Nishikyōku, } \\
\text { Kyoto }\end{array}$ & \\
\hline 1928 & \begin{tabular}{|l} 
句仏上人句碑 \\
「禹に勝る業や心の花盛」
\end{tabular} & $\begin{array}{l}\text { Shinanogawa,Tsubame } \\
\text { City, Niigata Prefecture }\end{array}$ & \multirow{3}{*}{$\begin{array}{l}1931 \text { Mukden Incident } \\
1937 \text { Start of Sino- } \\
\text { Japanese War } \\
1939 \text { World War II }\end{array}$} \\
\hline 1936 & 文命用水碑 & $\begin{array}{l}\text { Sakawagawa, Nishibe, } \\
\text { Kanagawa Prefecture }\end{array}$ & \\
\hline 1936 & $\begin{array}{l}\text { 砂防記念碑 } \\
\text { 「開荒成田禹績豹功垂」 }\end{array}$ & $\begin{array}{l}\text { Uonogawa, } \\
\text { Minami Uonumagun, } \\
\text { Niigata Prefecture }\end{array}$ & \\
\hline 1937 & $\begin{array}{l}\text { 古市公威像 } \\
\text { 「不譲大禹疏霊之功」 }\end{array}$ & $\begin{array}{l}\text { Front Gate, Tokyo } \\
\text { University, Bunkyo-ku, } \\
\text { Tokyo }\end{array}$ & \multirow{2}{*}{1945 End of the War } \\
\hline 1954 & $\begin{array}{l}\text { 大槫川水門改築記念碑 } \\
\text { 「禹功門」 }\end{array}$ & $\begin{array}{l}\text { Ibigawa, Yōrōgun, Gifu } \\
\text { Prefecture }\end{array}$ & \\
\hline 1972 & $\begin{array}{l}\text { 大禹謨 } \\
\text { 「大禹謨」 }\end{array}$ & $\begin{array}{l}\text { Ōtagawa, Hirsohima City, } \\
\text { Hiroshima Prefecture }\end{array}$ & \multirow{2}{*}{$\begin{array}{l}1965 \text { Treaty of Basic } \\
\text { Relations between Japan } \\
\text { and the Republic of } \\
\text { Korea }\end{array}$} \\
\hline \multicolumn{3}{|c|}{$\begin{array}{l}1972 \text { Normalization of relations between Japan and China } \\
1977 \text { Cultural Revolution declared over } \\
1978 \text { Signing of the Japan-China Treaty of Peace and } \\
\text { Friendship } \\
1992 \text { Normalization of relations between China and Korea }\end{array}$} & \\
\hline
\end{tabular}




\section{Background of the Building and Maintenance of Relics for Yu the Great}

As mentioned above, relics of Yu the Great were found in 92 places as of April, 2015, but since we are investigating relics in 15 more places, we will likely be able to verify over 100 locales with relics. If we analyze the sequence of building and survival of each monument, it is my opinion that we can see these monuments today because of the following three conditions:

First, (A), in order to convey the information to future generations, the words inscribed on monuments for completion of large renovation projects such as levees and water ducts in regions with frequent flood damage say "prayers for disaster prevention and productivity." This is a reason to build monuments to $\mathrm{Yu}$ the Great, so I will call it a necessary condition.

Next, (B) Confucian scholars and engineers familiar with Yu the Great (Wenming) should be involved with the monuments and there must be sufficient description of $\mathrm{Yu}$ or Wenming, such as "this construction is at a level of completion that rivals the trials and tribulations of the flood control achievements of Yu the Great (Dayu)." This I call a sufficient condition. Even if both conditions are present and monuments to $\mathrm{Yu}$ the Great are built, if there is no lasting knowledge of $\mathrm{Yu}$ in the area in question, the legacy will not continue to the present.

(C) That is, when there is support by a continuing regional culture for lasting recognition of the value of the monuments built to $\mathrm{Yu}$ the Great, they will endure, a condition I call a preservation condition.

I have been informed of the historical fact that monuments to $\mathrm{Yu}$ the Great were built in addition to the 92 locales mentioned above, but several have gone to ruin and thus do not meet condition (C). Continuing regional support is an important condition for maintaining existence. The $\mathrm{Yu}$ the Great Summits that have been convened in rotation in all areas of the country have been praised for contributing to condition $(\mathrm{C})$, the cultivation of support. I have attempted verification in the chart below of the three aforementioned conditions (A, B, C) for the Yu the Great Summits convened in five locales between 2010 and 2015 .

\begin{tabular}{|c|c|c|c|}
\hline $\begin{array}{l}\text { 遺跡名(所在地) } \\
\text { (禹王サミット } \\
\text { 開催年·開催地) } \\
\text { Monument name } \\
\text { (Place) (Year and } \\
\text { Location of Summit) }\end{array}$ & $\begin{array}{l}\text { (A) 自然災害 } \\
\text { (Natural Disaster) } \\
\text { 多発地に防災祈願、豊穣祈 } \\
\text { 願し建立 } \\
\text { Prayers for productivity } \\
\text { and prevention of } \\
\text { disasters where they are } \\
\text { common }\end{array}$ & $\begin{array}{l}\text { (B) 禹を熟知する治水家、 } \\
\text { 儒学者、行政TOPの存在 } \\
\text { (B) Flood control special- } \\
\text { ists, Confucianists and } \\
\text { government leaders } \\
\text { familiar with Yu the } \\
\text { Great }\end{array}$ & $\begin{array}{l}\text { (C) 禹遺跡の価值を認め継 } \\
\text { 承し続ける地域文化の存在 } \\
\text { (C) Existence of regional } \\
\text { culture that continues } \\
\text { recognizing the value of } \\
\text { monuments to Yu the } \\
\text { Great }\end{array}$ \\
\hline
\end{tabular}




\begin{tabular}{|c|c|c|c|}
\hline $\begin{array}{l}\text { 1)文命碑·文命宮 } \\
\text { (2010年神奈川県) } \\
\text { Wenming } \\
\text { Monument and } \\
\text { Shrine (2010; } \\
\text { Kanagawa Pref.) }\end{array}$ & \begin{tabular}{|l} 
( 酒㫐川 \\
(洪水多発地) \\
Sakawagawa River \\
(Area of much flooding)
\end{tabular} & $\begin{array}{l}\text { () 田中丘隅、荻生徂徠 } \\
\text { Tanaka Kyūgū, Ogyū } \\
\text { Sorai }\end{array}$ & $\begin{array}{l}\text { ○ 289年間、文命祭り継続 } \\
\text { Has continually held the } \\
\text { Bunmei (Wenming) } \\
\text { Festival for } 289 \text { years }\end{array}$ \\
\hline $\begin{array}{l}\text { (2)大禹皇帝碑 } \\
\text { Emperor Dayu } \\
\text { Monument } \\
\text { (2012年群馬県) } \\
\text { (2012; Gunma } \\
\text { Pref.) }\end{array}$ & $\begin{array}{l}\text { (片品川 } \\
\text { (洪水多発地) } \\
\text { Katashinagawa } \\
\text { (Area of much flooding) }\end{array}$ & 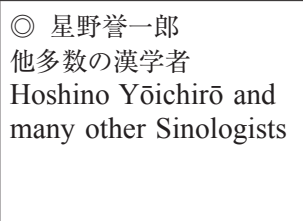 & $\begin{array}{l}\text { () 131年間存続 } \\
\text { Extant for } 131 \text { years }\end{array}$ \\
\hline $\begin{array}{l}\text { (3)大禹謨 } \\
\text { (2013年香川県) } \\
\text { Dayumo } \\
\text { (2013; Kagawa } \\
\text { Pref) }\end{array}$ & $\begin{array}{l}\text { ( 香東川 } \\
\text { (洪水多発地) } \\
\text { Kōtōgawa } \\
\text { (Area of much flooding) }\end{array}$ & $\begin{array}{l}\text { (ㅇ) 西嶋八兵衛、平田三郎 } \\
\text { Nishijima Hachibe’e } \\
\text { Hirata Saburō }\end{array}$ & $\begin{array}{l}\text { @ } 378 \text { 年前建立 } \Rightarrow \text { 洪水で } \\
\text { 行方不明 } \Rightarrow 1913 \text { 年発見 } \Rightarrow \\
\text { 1945年平田三郎再発見 } \\
\text { Built } 378 \text { years ago after } \\
\text { flooding Went missing } \\
\text { after a flood, discovered in } \\
1913 \text { and rediscovered in } \\
1945 \text { by Hirata Saburō }\end{array}$ \\
\hline $\begin{array}{l}\text { (4)大禹謨 } \\
\text { (2014年広島県) } \\
\text { Dayumo } \\
\text { (2014; Hiroshima } \\
\text { Pref) }\end{array}$ & $\begin{array}{l}\text { 太田川 } \\
\text { (洪水、土砂災害) } \\
\text { Ōtagawa } \\
\text { (flooding, landslides) }\end{array}$ & $\begin{array}{l}\text { (○) 池田早人 } \\
\text { Ikeda Hayato }\end{array}$ & $\begin{array}{l}\text { () } 1972 \text { 年建立 } \\
\text { Built in } 1972\end{array}$ \\
\hline $\begin{array}{l}\text { (5)禹禤合祀之碑 } \\
\text { (2015年大分県) } \\
\text { Ushoku Gōshi no hi } \\
\text { (2015; Ōita Pref) }\end{array}$ & $\begin{array}{l}\text { () 臼杵川 } \\
\text { (洪水、蝗害) } \\
\text { Usukigawa } \\
\text { (flooding, locust plagues) }\end{array}$ & $\begin{array}{l}\text { (荘田子謙、正田不久 } \\
\text { Shōda Shiken, Hikita } \\
\text { Fukan }\end{array}$ & $\begin{array}{l}\text { (275年間、禹王塔祭り継 } \\
\text { 続 } \\
\text { Has continuously held Yu } \\
\text { the Great Pagoda } \\
\text { Festival for } 275 \text { years }\end{array}$ \\
\hline
\end{tabular}

To elaborate on the Wenming monuments and Wenming shrines in the Sakawagawa River basin in Number 1 in the chart above:

(A) Sakawagawa often overflows its banks; in approximately the last 400 years it has caused severe flood damage once every thirteen years. In particular, after the Hōei eruption of Mt. Fuji in 1707, flood damage was immense over the next one-hundred years. After 1708, when about five or six meters of volcanic ash continued to pile up on the river bottom, the embankment was eroded until the local villages disappeared under floods..

(B) By the order of the eighth shogun, Tokugawa Yoshimune, who could not ignore the terrible plight of the villagers, what could be called our country's first nationally managed engineering project began on the Sakawagawa River. Through the efforts of Provincial Governor Ōoka Echizen 大岡越前 (politician), Tanaka Kyūgū 田中丘隅 (waterworks engineer), and Ogyū Sorai 荻生徂徠 (Confucian scholar), a Wenming embankment was completed through a large-scale flood control project, and prayers for disaster prevention and productivity (Wenming Festival) was held on a massive scale. Tanaka 
Kyūgū and the others entrusted pacification of the Sakawagawa River to the god of flood control of the Yellow River in China, Wenming (Yu the Great). This was in 1726 .

(C) In the Sakawagawa River basin, the Wenming Festival has been held without fail for 289 years, from 1726 to 2015 . There is a record that indicates the festival was held solemnly even during the Meiji Restoration (1868). There is no doubt that the festival has continued because of a deep-rooted interest on the part of local residents and the understanding and support of local government (Minami Ashigara City, Kanagawa Prefecture, Yamakita-chō, Kaiseimachi, etc.). It is of profound significance that the seventh annual conference of the Society for Cultural Interaction Studies in East Asia (SCIEA) was held there in May, 2015.

\section{Basis for Bunmei-sha Shrine (Now Called the Fukuzawa Jinja Shrine) Built on the Sakawagawa River Levee}

As I mentioned in the last section, the Sakawagawa River Wenming Monument and Bunmei-sha were built in 1726 on the grounds of the main Shinto shrine, Bunmei-kyū. In 1909 Bunmei-sha was united with ten surrounding shrine buildings and renamed Fukuzawa Jinja, where "King Yu of Xia" is still the deity worshipped. I will here outline how this came about. 


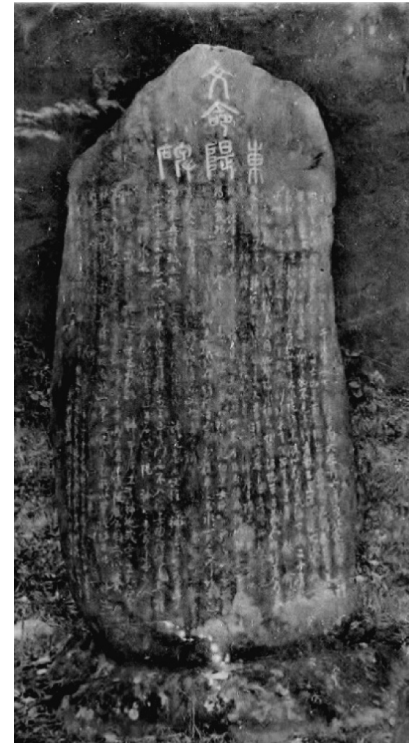

A

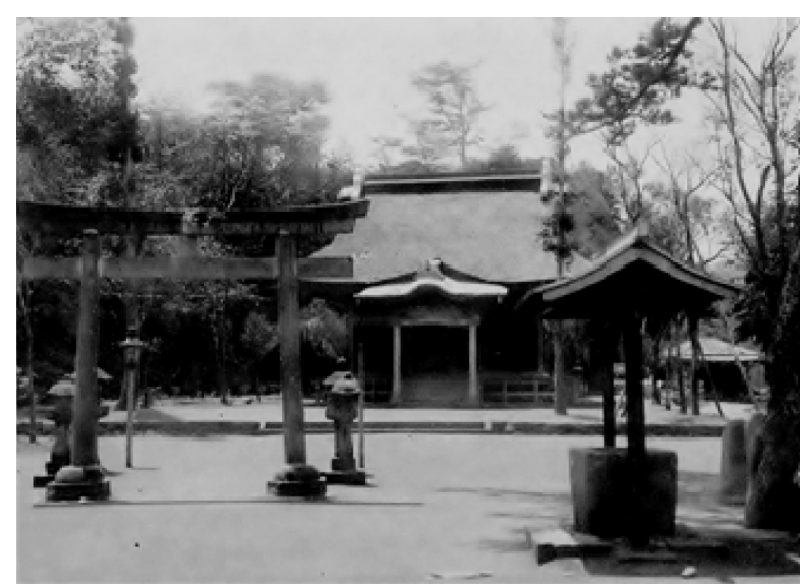

B

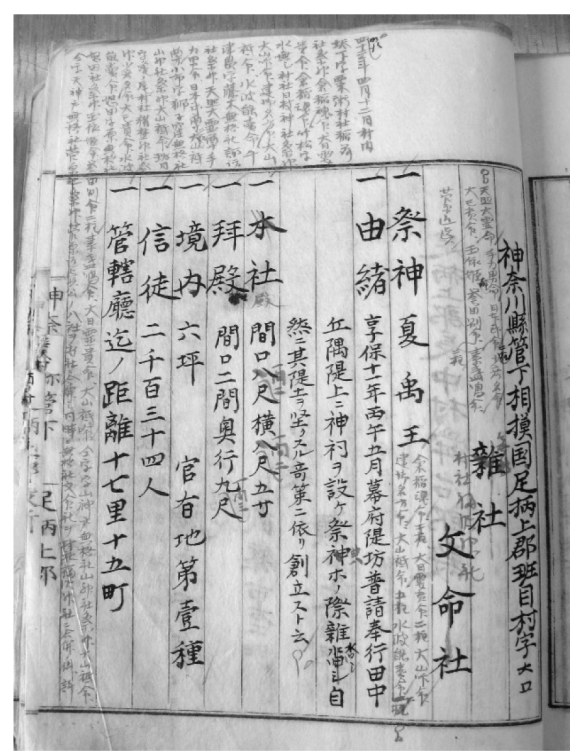

C

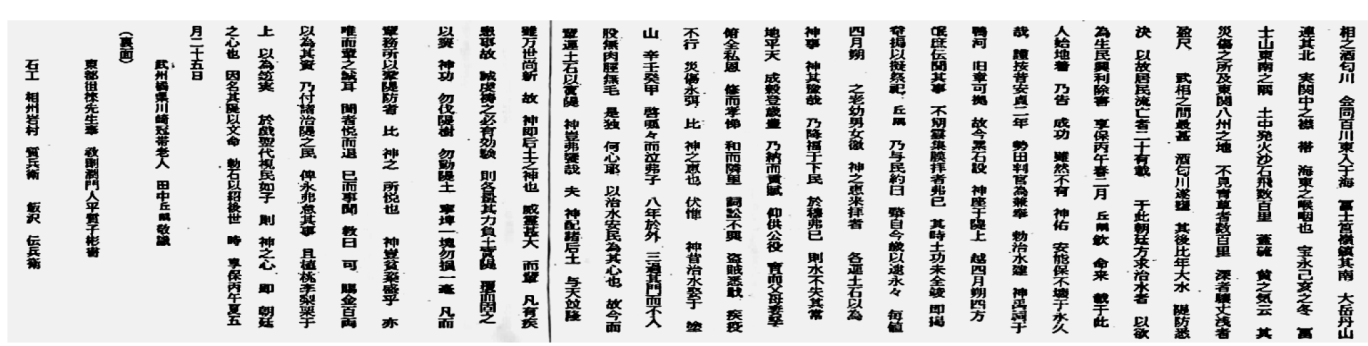

D 
*Photos A and B were both issued in 1900 as "Postcards of Famous Places in Japan." They are in this author's possession. A is the oldest photo of the Wenming east embankment monument. B is the oldest photo of Bunmei-sha. The image in photo A was located on a cliff (Sengan-iwa Cape) at the back of the main hall of Bunmei-sha. It has now moved to the right side of the torii gate.

*Photo B is the oldest photo of Bunmei-sha which was built in April 1726 by Tanaka Kyūgū

Enshrined deity: King Yu (Yu the Great) of Xia

History: Built with 100 ryō (gold coins) of government money by the Bakufu as a center of disaster prevention for the Sakawagawa River. Every May for the last 289 years a farm implement market festival has been held on the embankment.

*Photo $\mathrm{C}$ is a page from the shrine ledger 神社明細帳 (Jinja meisaichō) published by the Ashigara Kamigun government office of Kanagawa Prefecture in 1879. It states that the enshrined deity is King Yu of Xia.

*Photo D is the entire text of "Wenming East Embankment Monument" (unpunctuated Chinese text). Tanaka Kyūgū gave his document to shogun Tokugawa Yoshimune via Provincial Governor Ōoka Echizen. Yoshimune ordered the Confucian scholar Ogyū Sorai to polish the writing, resulting in highly refined Chinese. In 1222, a miniature Shinto shrine for the deity Yu was placed on the Kamogawa levee in Kyoto for safety and protection. At the Sakawagawa River a festival is also held. People are asked to carry stones to the embankment and pack them down with their feet. (lines 9-11).

\section{Yu the Great (Bunmei) in Classical Japanese Literature}

There are now finally 100 places where relics of Yu the Great have been located. Here we will look at how Yu (Bunmei) has changed in the Japanese culture that supports the creation of these relics by examining Yu in classical Japanese literary history and the history of flood control.

In ancient Japan around the year $100 \mathrm{BC}$, over one-hundred small kingdoms competed with one another, and there was no guiding political agency to unify them. In about the second or third century AD, these were unified as the Yamato alliance, which was attempting to organize itself into the form of a country. In around 670 the Kingdom of Wa (Yamato) was renamed Nippon (Japan). During this period, it was necessary to imbue the land with authority and absorb advanced culture and technology for formation of the country. It is said that Japan coveted interaction with continental culture for this purpose; the following two main routes are considered to have enabled the flow of culture into Japan:

\section{A. Route directly from China}

Early contact with ancient China (fifth to third centuries BC: importation of rice cultivation, ironware, and other advanced technologies in the Yayoi and Yamato periods). 
Import of culture, technology, and Han Chinese people by Japanese emissaries to Sui and Tang China (599-835)

B. Korean peninsula route

Han Chinese from the Lelang (楽浪) and Daifang (帯方)Commanderies in Korea (about 300 BC)

Peninsular peoples from Baekje and other areas brought culture and technology (fourth to sixth centuries)

(1) It is likely that as soon as Chinese culture began flowing into Japan around the beginning of the common era, the Four Books and Five Classics (四書五經; Sishu wujing) and Records of the Grand Historian (史 記) were the first to be imported.

It is thought that through these works or through the oral transmission of Han Chinese, stories about Yu the Great (Wenming), such as Yu as controlling the Yellow River and the benevolence and the nobility of his moral conduct, were repeatedly introduced to Japan and awareness of him spread.

285 BC The scholar Wani (王仁) from Baekje arrived at the capital and transmitted to Japan The Analects 論語 (Lunyu) and The Thousand Character Classic 千字文 (Qianziwen)

513 AD Arrival in the Japanese court from Baekje of the system of government based on the Five Classics 五経博士 (Wujing boshi)

554 AD Arrival in the Japanese court from Baekje of the system of government based on the Five Classics (Wujing boshi)

Doubtless there are many other stories of Yu the Great (Wenming) that arrived in Japan directly from China or through the Korean peninsula other than the historically verified ones above. According to a catalogue of Chinese texts that were extant in the early Heian period in Japan, Nihon-koku genzaisho mokuroku 日本国見在書目録 (Catalogue of Extant Japanese Works; Imperial Household Archives), it is possible to have a certain level of inferred verification of such stories.

(2) Evidence of the fact of transmission to Japan of the Four Books, Five Classics, and Records of the Grand Historian as seen in the Nihonkoku genzaisho mokuroku 
1) The Nihon-koku genzaisho mokuroku is the oldest catalogue of Chinese texts in Japan, having been compiled between 875 and 891. It is an important document for learning about every Chinese book that had come to Japan by the beginning of the Heian period. The word genzai means "extant." Perusing the book, we can verify that there were 1579 Chinese texts extant at the time and that texts containing descriptions of Yu the Great (Wenming) did indeed arrive in Japan. There are 1579 listed volume numbers and it is surmised that the six books with descriptions of Yu (Wenming) are preserved nearly in their entirety.

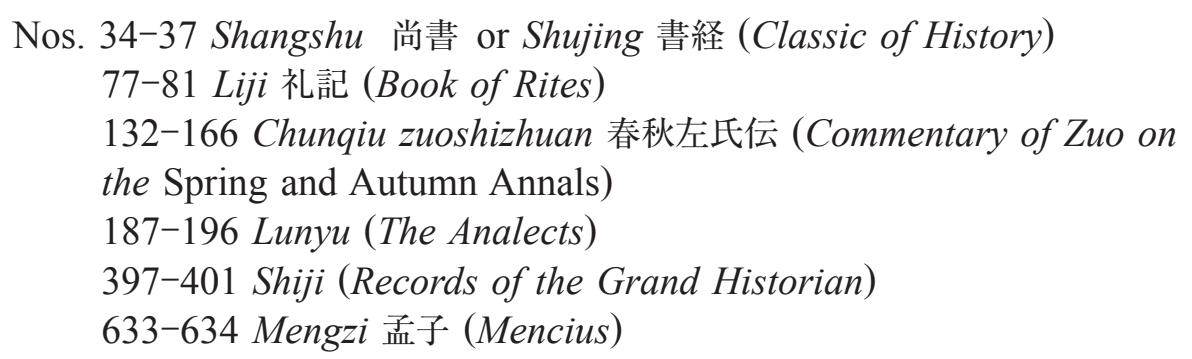

As can be seen above, there is corroboration that many Chinese texts containing stories of Yu (Wenming) had arrived in Japan by at least the year 870 .

2) It is noted on the Wenming east embankment monument at the Sakawagawa River that "in 1228 flood control of the Kamogawa River was carried out at the royal command of the judge of Seta, Tamekane (為兼); a small shrine to $\mathrm{Yu}$ the Great was built and prayers were said for a safe Kamogawa River." Thus, it could be said that there was sufficient background in Kyoto in the 1200s for making reference to the flood control god, $\mathrm{Yu}$ the Great. There are Chinese texts besides the Four Books, Five Classics, and the Records of the Grand Historian in the Nihon-koku genzaisho mokuroku that contain descriptions of Yu (Wenming), such as the Huainanzi (准南 子), Shanhaijing 山海経 (Classic of Mountains and Seas), Zhenguan zhengyao 貞観政要 (Essentials of Government in the Zhenguan Reign, Eighth Period), Qianziwen 千字文 (Thousand Character Classic), Zhuangzi, Wen Xuan 文選 (Selection of Refined Literature), and Liezi. (列子).

\section{(3) How the subject of Wenming (Yu the Great )was treated in Japan}

1) General remarks

Chronology of writings on the benevolence and nobility of Wenming's (Yu's) moral conduct: 
古事記 Kojiki (Records of Ancient Matters) $\Rightarrow$ 日本書記 Nihon Shoki (The Chronicles $\overline{\text { of Japan) }} \Rightarrow$ 空海 Kūkai (三教指帰 Sangō shiki、性霊集 Shōryōshū) $\Rightarrow$ 吉田兼好 Yoshida

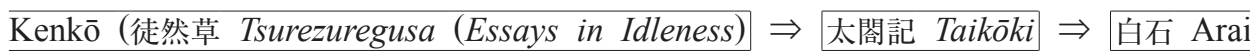
Hakuseki (折たく柴の記 Oritaku shibu no ki) $\Rightarrow$

荻生徂徠 Ogyū Sorai (政談 Seidan (Discourse on Government)、諼園雑話 Kenen $\overline{\text { zatsuwa) }} \Rightarrow$ 柳沢淇園 Yanagisawa Kien (ひとり寝 Hitorine) $\Rightarrow$ 梅岩 Ishida Baigan (都 鄙問答 Tohi Mondō)

Chronology of works that extol the achievements of the flood control of Wenming (Yu) and an attempt to tap into the legacy of the god of flood control.

日本全国 Japan nationally: 三锓記 Mitsuboki $\Rightarrow$ 政談 Seidan ·諼園雑話 Kenen $\overline{\text { zatsuwa }} \Rightarrow$ 厞風柳多留 Haifü yanagidaru $\Rightarrow$ 風来山人集 Fürai sanjinsh $\bar{u} \Rightarrow$ 地方凡例 録 Jikata hanreiroku

鴨川治水 Control of Kamogawa River flooding : 相国寺荃涼軒日録 Shōkokuji $\overline{\text { Inryōkennichiroku } \Rightarrow \text { 洛中洛外図 Rakuchū rakugaizu } \Rightarrow \text { 雍洲府志 Yōshū fushi } \Rightarrow \text { 諼園 }}$ 雑話 Kenen zatsuwa $\Rightarrow$ 山城名所巡行記 Yamashiro meisho junkōki

2) Various discourses, part 1 (Japan nationally)

Kojiki (edited by Ōno Yasumaro 太安万, 712): description of Wenming

Synopsis of section related to Yu: “The name of the Genmei (元明) Empress at the time was more exalted than Wenming of Xia and the greatness of her benevolence was superior to King Tang of Shang" $\Rightarrow$ Perhaps this was an opportunity to raise awareness among the imperial family (Note: The Genmei Empress reigned from 707 to 715 ).

Nihon shoki (completed in 720). On the page about Emperor Kōtoku 孝 徳 (reigned 645-654) in the Nihon Shoki there is a paean to Emperor Kōtoku that draws on the benevolent actions of Yu the Great.

Sangō shiki (Written by Kūkai 空海 around 797; explains the inferiority or superiority of Confucianism, Daoism, Buddhism, and the superiority of Buddhism). Synopsis of treatment of Yu: If you disparage goodness and say many incorrect words, your blood relatives will also be destroyed. The words and deeds of a wise man are related to renown and shame. If it were Yu the 
Great, what would he do? (Note: Kūkai was the fourteenth emissary to Tang China; he went there to study to be a Buddhist priest in 804.)

Shōryōshū (a collection of Kūkai's Chinese poetry edited by his disciple, Shinzei 真済,between around 800 and 860).

Synopsis of treatment of Yu: "King Yu of Xia saw those who sinned, reflected on his own lack of virtue and severely judged himself."

Tsurezuregusa (collection of essays by Yoshida Kenkō 吉田兼好 written around 1330, the end of the Kamakura period)

Synopsis of the $171^{\text {st }}$ stanza: "When the Min tribes of southern China continued to rebel and came to a deadlock, King Yu withdrew the troops and turned toward implementing a benevolent government. When he did that, the Min tribes were impressed by his benevolence and surrendered."

(Note: this is thought to be quoted from the Dayumo 大禹謨volume of the Shujing 書経.)

Taikōki (written by Oze Hoan 小瀬甫庵in 1625)

Synopsis of section related to Yu: "The people worthy of being entrusted with the divine jewel of the nation were two emperors (Yao and Shun) and three kings (King Yu, King Tang, and King Wu) of ancient China.”

Mitsuboki (Maeda clan of Kaga, Kaga domain historical document)

Synopsis of section related to Yu: "In 1594 Hideyoshi went to observe the flood control of the Uji River he had commanded of Maeda Toshiie前田 利家. Hideyoshi, who watched Toshiie take the lead with a shovel himself, said, 'For the Great Councilor himself to get involved is like King Yu of Xia using a shovel to divert the flood and save the people."

Further, I touched earlier in the section about Yu relics on the custom in the Meiji period of quoting Yu the Great's flood control to praise personal achievements. The example by Hideyoshi in Mitsuboki is possibly the origin of this practice.

Oritaku shiba no ki (written by Arai Hakuseki 新井白石 in 1716)

Synopsis of section related to Yu: "The commissioner of finance in the bakufu had an important duty, but if I were to give an example from ancient times of someone who excelled at his duties, I can only think of Yu the Great." 
Seidan (there are various theories; I am using the theory that it was published in 1722. It was written by Ogyū Sorai 荻生徂徚 himself)

There are several places where Yu the Great is mentioned. Synopsis of the first volume: "Governing the country is like cutting a go board into squares. A go board cannot be played without board squares. If there is no river course for controlling floods, the water cannot be controlled even if $\mathrm{Yu}$ the Great comes back to life today."

Hitorine (written in 1725 by Yanagisawa Kien 柳沢淇園. His father was chief retainer under Yanagisawa Yoshiyasu 柳沢吉保, the feudal lord, and Kien himself was a disciple of Ogyu Sorai. It is considered the most literary of the essays written in the early modern period.)

Synopsis of section related to Yu: "Most prosaic people tried to get rich quickly with five rin [translator's note: one rin is one/one-thousands of one yen] of gold. Yu the Great did not want to spare even a moment and continued working steadily."

Tohi mond $\overline{\boldsymbol{o}}$ (canon on moral philosophy expounded by Ishida Baigan 石 田梅岩 in 1739. Baigan was a central figure in the movement for social education in Kyoto.)

Synopsis of section related to Yu: "In order to go forward, benevolence is essential. For example, when the tribes in the south did not follow orders and much trouble was involved in reaching a solution, Yu the Great withdrew the troops. When he did so, the tribes who had rebelled so much voluntarily retreated. This is an example of benevolence."

(Note: similar to the quote in Tsurezuregusa).

Haifü yanagidaru (a seminal collection of senry $\bar{u}$ 川柳 poems and kyōgen written between 1765 and 1788) in which the author, Ekiraku 亦楽, is said to have written the poem, "I made Yu control the flooding. I see no faults in him."

Fūrai sanjinsh $\overline{\boldsymbol{u}}$ (written by Hiraga Gennai 平賀源内 in 1770. Though known as a playwright, Gennai also used the pen name, Fūrai sanjin 風来山 人.)

Synopsis of section related to Yu: "They say that wise people like water and men of virtue like the mountains. Houji 后稷 taught farming and $\mathrm{Yu}$ the 
Great controlled flooding. The path of a saint is to decrease excess and supplement what's lacking."

Jikata Hanreiroku (written by Ōoishi Hisataka 大石久敬 around 1788)

Considered a book of rules for controlling self-governing peasants for local officials, from county and local magistrates to village officials, the book was used for reform of taxation and organizing local systems during the early Meiji period. "The officials in charge of maintaining government offices in Volume 9" contains a detailed explanation at the beginning about Yu's achievements in flood control.

(Note: perhaps quoted from the Shiji)

Kōmō tōki (Expositions of the Teachings of Confucius and Mencius; written by Yoshida Shōin 吉田松陰 in 1855)

The book laments the lack of experience of hardship on the part of contemporary rulers by comparing them to $\mathrm{Yu}$ the Great: "Yu controlled flooding and after he married Tushan (塗山) he left home just four days later. His toils can only be described as prodigious. However, rulers in succeeding generations couldn't even imagine his trials and tribulations."

\section{3) Various essays, part 2 (documents that list shrines to Yu the Great found in Kamogawa, Kyoto)}

Shōkokuji Inryōkennichiroku (on page for August 21, 1488). There is a yashiro 社 Shinto shrine below the Gojō Bridge; it is said to be a shrine dedicated to Yu of Xia.

Rakuchū rakugaizu (Uesugi and Machida screens (painted by 1549). There is a Daikokudō (Yu Shrine) at the Gojō Bridge.

Yōshū fushi (written by the Confucian doctor Kurokawa Dōyū 黑川道佑 in 1686 ; best chorography in the $17^{\text {th }}$ century)

Synopsis of section related to Yu: There is a shrine to King Yu of Xia in the dry riverbed at the old Gojō Bridge. At the Yamatobashi bank in ShijōŌhashi Higashi-zume there is a Benzaitensha弁財天社shrine.

Kenen zatsuwa (collection of the anecdotes of Ogyū Sorai, written around 1726)

Synopsis of section related to Yu: At the upper reaches of the Sakawagawa River they build a monument to $\mathrm{Yu}$ the Great and give it to Provincial 
Governor Ōoka Echizen 大岡越前. In the inscription, Hattori Nankaku 服部南 郭 is asked: "Please give the source for the information that the judge of Seta, by imperial command, ordered the building of a shrine on the Kamogamo River to the god Yu, who controls flooding." He answers, "I saw it in the Yōshū fushi."

Yamashiro meisho junkoki (published in 1754)

Synopsis of section about Yu: Yu the Great is enshrined in the Shinmei Shrine (神明社) at Shijōo-Ōhashi Higashizume.

Miyako meishozue (published in 1780)

Synopsis of section related to Yu: "There is a shrine to Yu the Great near south Shijō. He is a god that calms the waters."

Hengaku kihan (published about 1820)

Synopsis of section related to Yu: "In Chūgenji in Shijō-Ōhashi Higashizume."

\section{4) The Imperial Family and Yu the Great (Wenming):}

Yu the Great's benevolence embellishes the daily moral teachings of the imperial family

Kyoto Gosho (Palace) There is a fusuma sliding door painting entitled “Daiu Kaishu Bōbizu" (大禹戒酒防微図) that depicts stories of Yu the Great in the Otsune Palace (御常御殿) as a reminder to practice self-control. Yu the Great has been enshrined in a place in the Emperor's daily life from long ago, and the Emperor has seriously learned from China. I am impressed deeply by these facts. The fusuma painting today is a piece of art from 1855, but it is said that "Daiu Kaishu" was first brought into the palace in 1641.

Kojiki (in the preface written in 712, during the reign of Empress Genmei) the empress and Wenming are listed.

"Prostrate I consider how her Majesty the Empress, having obtained Unity, illumines the empire, - being versed in the Triad, nourishes the people. Ruling from the Purple Palace, Her virtue reaches to the utmost limits of the horses' hoofmarks: dwelling amid the Sombre Retinue, Her influence illumines the furthest distance attained to by the vessels' prows. The sun rises, and the brightness is increased; the clouds disperse, neither is there smoke. Never cease the historiographers from recording the good omens of connected stalks and double rice-ears; never for a 
single moon is the treasury without the tribute of continuous beaconfires and repeated interpretations. In fame She must be pronounced superior to Bum-Mei [Wenming], in virtue more eminent than Ten-Itsu [King Tang of Shang]. [Translation by Basil Hall Chamberlain, The Kojiki (1906), Tuttle Publishing (1981), pp.11-12].

Note: Synopsis of the underlined section: Her Majesty the Empress (Genmei Empress)...in fame...must be pronounced superior to [Wenming], in virtue more eminent than [King Tang of Shang]. Through the Kojiki, we can surmise that the imperial family was aware of Wenming (Yu the Great) from ancient times.

\section{Research Groups throughout the Country: Starting Research Committees on the Flood Control God Yu the Great}

Through the cooperation of Professor Uemura Yoshihiro of Bukkyō University, we convened a "Yu the Great Research Society in Kyoto" in 2011 and 2012. It was very natural to organize a group with our fellow researchers whose numbers had grown nationally through the Summits we had held. Two types of action were taken from the interchanges of our colleagues. One was a Yu the Great monument tour of China held three times from 2011. The second was the publication in 2013 of a book entitled Chisuishin Uōo tazuneru tabi (治水神禹王をたずねる旅) [Travels to Visit the Flood Control God, King Yu], edited by Ōwaki Yoshio (大脇良夫) and Mr. Uemura Yoshihiro (植村善博) and published by Jinbunshoin Press. This energy linked to inauguration of the "Flood Control God Yu the Great Research Society" in July, 2013. This author was the first chairman. The vice chairman was Mr. Uemura Yoshihiro, and our advisers were Professor Wang Min (王敏) of Hōsei University, and Mr. Tsuyuki Junichi (露木順一氏), former mayor of Kaiseimachi and professor at Nihon University. The current number of members is 111. The oldest is 85 and the youngest, 24. Lastly, I would like to mention something about the name of the town of Kaiseimachi, Kanagawa Prefecture, where I reside.

Kaisei is from kaiwu chengwu (開物成務) in one of the books fundamental to Confucianism in the Chinese classics, the Yijing易経(Book of Changes). It means "develop people's knowledge and work for development of society." It shows enthusiasm for cultivating people and enriching the region as well as holding the long view. The name Kaisei was established in 1882 and the town formulated a "Human Development Charter" in 2009. My Chinese friend, Ms. Cui Zhen (崔貞), was so impressed that she translated it into Chinese for me recently. I would like to conclude this essay by introducing it. 

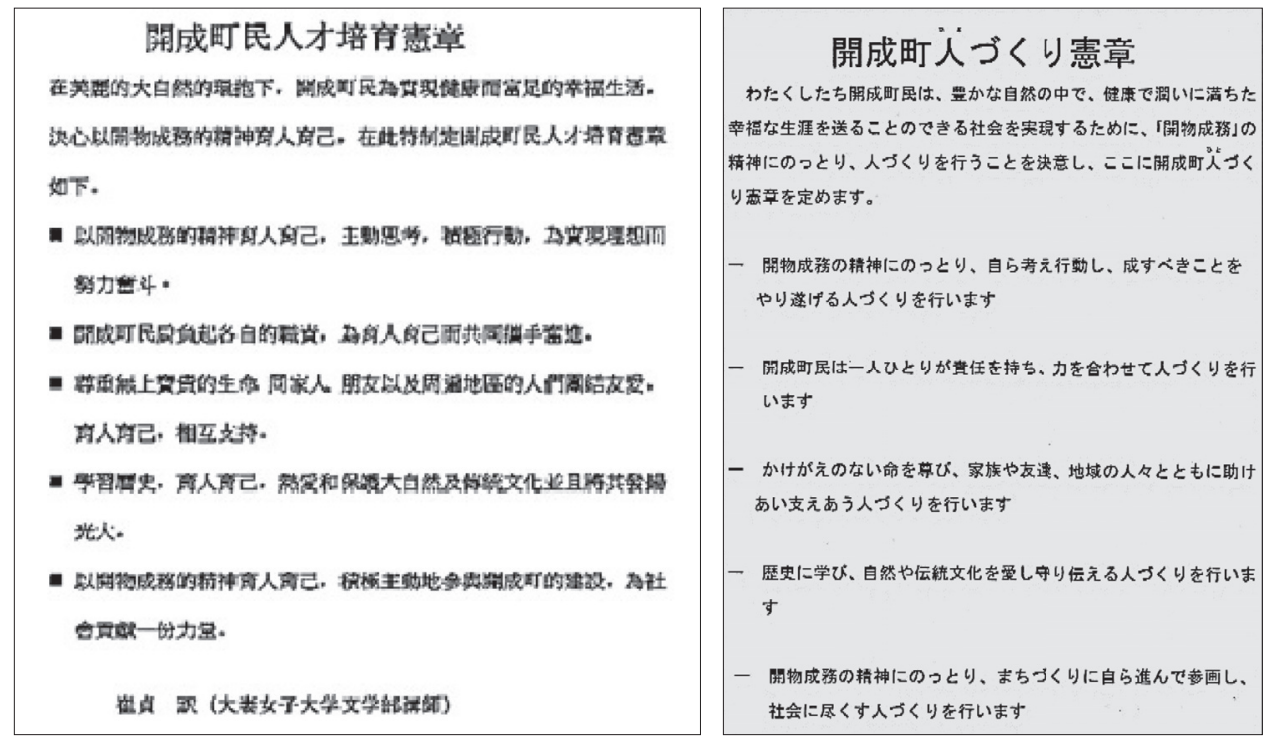

\section{English Version of the Human Development Charter of Kaiseimachi}

We the people of Kaiseimachi do hereby declare in this Kaiseimachi Human Development Charter that in order to realize a society where we can live healthy, fulfilling, and happy lives surrounded by a rich natural environment, we will foster a spirit of "developing people's knowledge and working for development of society" by resolving to cultivate human development.

We will adopt the spirit of developing people's knowledge and working for development of society and foster development of people who can think and act for themselves, and thus complete what must be done.

Each resident of Kaiseimachi will take responsibility for him or herself, and cooperate to foster human talent.

We will value life, which is irreplaceable, and cultivate people who will support and help family, friends, and people in the area.

We will cultivate people who learn from history, and love, protect, and pass on nature and traditional culture.

We will adopt the spirit of developing people's knowledge and working for development of society, participate actively ourselves in building the community, and cultivate people who will do their best for society. 